\title{
Oscar Wilde's Aesthetics in the Making: The Reviews of the Grosvenor Gallery exhibitions of 1877 and 1879)
}

This paper explores the first two texts Wilde published in 1877 and 1879 in Irish periodicals, which are reviews of the first and third exhibitions of the Grosvenor Gallery in 1877 and 1879. Wilde commented on the developments that had been affecting British painting for the past fifteen years or so. He addressed the works of artists who were then associated with the "classic" school of painting as well as with "Aestheticism"- which often overlapped. Moreover, he engaged in a dialogue with the reviewers and art critics who were favourable to such art. It was in such fermenting soil that Wilde's aesthetics was grounded and this essay proposes in particular to explore the aesthetics of ambivalence and ambiguity which characterized these artworks and which becomes central in these two reviews.

En 1877 et 1879, Wilde publie dans des périodiques irlandais des comptes rendus des première et troisième expositions de la Grosvenor Gallery. Ces textes constituent un premier commentaire de Wilde sur les développements qui touchaient les arts visuels depuis une quinzaine d'années environ. Wilde évoque dans ces comptes rendus les œuvres d'artistes alors associés à «l'école classique » ou à l'«Esthétisme " (mouvements qui se recoupaient souvent). En outre, Wilde dialogue avec les commentateurs ou les critiques d'art qui étaient favorables à cette peinture. C'est dans ce terreau fertile que l'esthétique de Wilde prend forme, et cet article se propose en particulier d'explorer l'esthétique de l'ambiguïté et de l'ambivalence qui caractérise ces tableaux et qui apparaît comme centrale dans les deux comptes rendus de Wilde.

Wilde's first review, “The Grosvenor Gallery, 1877” was written for the Irish periodical Dublin University Magazine, and published in July 1877 (Dublin University Magazine, 11826). ${ }^{1}$ Wilde, who was probably busy with his academic studies at Oxford, wrote no review of the second exhibition of the Grosvenor Gallery of 1878. But in 1879, he published "The Grosvenor Gallery (First Notice)" in Saunders' Irish Daily News dated May 5, 1879 (5-6) in which he reviewed the third yearly exhibition. For reasons that still need elucidating, this piece was much shorter than the first one. Wilde even mentions that he intends to review the paintings shown, on "another occasion" (Wilde 1879, 26), but no such publication seems to have appeared, probably because he was engrossed in his exams. The second article is too short to consider any evolution between the two pieces, which is why they will be studied together here. The context for the first publication is well documented: having extended his trip to Italy and Greece, Wilde had absented himself too long and had been sent down by the University authorities. He thus went to London to make the most of his rustication from Oxford (Ellmann 76-8, Aquien 75-80) and took the opportunity to attend the opening of the Grosvenor Gallery. This had indeed been publicized as a major social and artistic event and Wilde, who had decided he would become an art critic, saw it as the perfect occasion to enter the journalistic arena. His début in the London world actually turned into a successful act of

The Dublin University Magazine ran from 1833 to 1882 and was first committed to politics and then to literature. Between 1878 and 1880, its name changed for The University Magazine: A Literary and Philosophic Review. Its position was mainly Protestant and Unionist. 
self-advertising, mostly due to the remarkable cello-shaped bronze-reddish coat he had designed.

Not only do the two articles of 1877 and 1879 record Wilde's early steps in the world of art criticism, before he made his living as a professional journalist; ${ }^{2}$ they are also the first statement of his aesthetic and artistic tastes. Wilde indeed declares his interest in the new aesthetics that had been promoted by a number of artists for the past fifteen years. His personal attraction to a type of artistic productions reflects the new aesthetic trends that found an important showcase in this exhibition. This essay, therefore, aims at exploring how Wilde was attracted to pictorial tendencies that were basically founded on polarities, eclectic influences, hybridity and ambivalences. Those reviews also provided him with an opportunity to align with other critics in the defence of that art and to choose his camp in the contemporary artistic debates. Yet Wilde's aesthetic is also highly personal and some elements of his later texts already come to the fore in these essays.

Wilde's article actually adopts the format and structure of many other contemporary reviews, which is quite coherent considering his wish to enter the journalistic arena. He provides informative elements about the "origin of the Gallery" and then describes the "Gallery itself" (Wilde 1877, 5), dwelling on the striking colours of the wallpapers, the disposition of the pictures and the decoration of the rooms; he introduces and concludes on a number of illustrious artists - whether present, like Edward Burne-Jones or George Frederic Watts, or absent, like Dante Gabriel Rossetti. He then selects artworks even as he perambulates in the gallery, stopping at this and that painting - another recurrent feature of contemporary journalism. The founders of the Grosvenor Gallery, Blanche and Sir Coutts Lindsay, who were rich patrons of the arts and artists themselves, had wanted it to be an innovative exhibition venue. It indeed displayed a number of artists who diverged from mainstream Victorian painting and whose works had sometimes been refused by the Hanging Committee of the Royal Academy. Besides, unlike that institution, there were only three exhibiting rooms, in which few artworks were hung, thus allowing the public to make the most of each work (for detailed studies of the Grosvenor Gallery, see Newall, Casteras and Denney). The West gallery exhibited the champions, the East Gallery displayed lesser-known works, and the Water-Colour Gallery showed the watercolours and sculptures. In 1877, the works illustrated a wide range of artistic styles. Some elicited the critics' attention and some

${ }_{2}^{2}$ Part of the immense material of signed or anonymous reviews Wilde wrote for various newspapers and journals between the mid-1880s and about 1890, on a vast array of topics, was edited by Ross in volumes IX (Reviews) and XIV (Miscellanies) of his 1908 Collected Edition and then in volumes VI (Journalism) and VII (Criticism and Historical Criticism) of the recent "Oxford English Texts" collection. 
failed to. There were a great many portraitists - some of them mentioned by Wilde and other reviewers. Present also were a number of landscape painters, some associated to the British Impressionistic school, and whose groundbreaking styles and techniques were either ignored or rejected by the critics. Many American or Continental painters, mostly French, exhibited their works there, such as James Tissot and Ferdinand Heilbuth, whom Wilde evokes. It was also an important venue for female artists and Wilde mentions a few of them.

Most prominent in the contemporary reception were the academic artists of the thenlabelled "classic" or "classical" school, ${ }^{3}$ who turned to Greece and Rome for their forms and subjects. These were generally close, both in terms of artistic aims and sociability, to the painters later grouped under the label of "Aestheticism". ${ }^{4}$ Those artists came in the wake of the Pre-Raphaelitism of the early 1850s and adopted an eclectic aesthetics which combined mythological, literary, medieval and non-narrative subjects. The term "Aestheticism" was not much in use then (see Prettejohn 1999, 1-7), but those painters shared a similar interest for beauty for its own sake, for synaesthetic effects, and for the evocation of mood. Most embraced a formalist approach to art in which form, line and colour played a prominent role. In fact, both these "classic" and "Aesthetic" trends in art generally turned to the beautiful forms of Greek classical statuary as the best way to reach abstract and sensory qualities of line and colour, which were considered as an end in themselves. In parallel, a number of art critics and theoreticians approached paintings through the valuation of the harmony of lines and colours and called for an aesthetic rather than an ethical attitude to art.

Wilde's two articles reflect the aesthetic revelation he experienced when faced with these paintings, which are situated at the confluence of classicism and Aestheticism. His account was most certainly sustained by thorough knowledge of the contemporary reception of these new artistic developments. For one thing, Wilde's review came out in July, slightly after most critical reviews had already come out in the numerous periodicals that regularly published signed or unsigned assessments of the main London exhibitions. ${ }^{5}$ To mention some of them, Sidney Colvin signed a review for The Fortnightly Review on June 21; so did William Michael Rossetti for The Academy on May 5 and May 26, and Henry Heathcote

\footnotetext{
${ }^{3}$ These terms recur in a considerable number of reviews published in periodicals of the time (see Barrow). Some of these artists have been categorized as "Aesthetic" but the term "classic" is quite convenient, as it includes other painters, such as E.J. Poynter, W.B. Richmond or Lawrence Alma-Tadema.

${ }^{4}$ Prettejohn uses the term "Art for Art's Sake" when discussing "Aesthetic" painters such as D.G. Rossetti, Albert Moore, Frederic Leighton, Simeon Solomon or James Abbot MacNeill Whistler (see Prettejohn 2007). Staley uses a chronological landmark - the decade of the $1860 \mathrm{~s}$ - as the turning point for the irruption of new pictorial trends as they are quite diverse in terms of subjects, styles and techniques (see Staley).

${ }^{5}$ Most reviews of the yearly summer exhibitions of the Royal Gallery and of the Grosvenor Gallery were published around May or June, sometimes in instalments.
} 
Statham for Macmillan's Magazine in June. Agnes Atkinson published an undated review for The Portfolio and there were other anonymous accounts in the Art Journal, The Illustrated London News or The Magazine of Art. There was also an unsigned review in The Times on March 12-probably by Tom Taylor, who was its art critic - and one in The Athenaeum on May 5-most certainly by its art editor, F.G. Stephens. Like other critics, beauty plays a central role in Wilde's aesthetic appreciation of such works (in the 1877 essay, for instance, there are twenty-two occurrences of the words "beauty", "beauties" and "beautiful"), and he elevates it to a near-cult. His conclusion reads like a manifesto: "Sir Coutts Lindsay, in showing us great works of art, will be most materially aiding that revival of culture and love of beauty which in great part owes its birth to Mr. Ruskin, and which Mr. Swinburne, and Mr. Pater, and Mr. Symonds, and Mr. Morris, and many others, are fostering and keeping alive, each in his own peculiar fashion" (Wilde 1877, 23). This is a declaration of allegiance to a number of theoreticians: in his essay on William Blake of 1867, the poet Algernon Charles Swinburne introduced the term "art for art's sake" in England and emphasized the role of beauty (see Swinburne); Sidney Colvin, in his seminal article "English painters and painting in 1867", addressed those innovative painters "whose aim, to judge by their works, seems to be pre-eminently beauty" (Colvin 1867, 473); ${ }^{6}$ Walter Pater ended his essay on the "Poems by William Morris" of 1868 with a special call for "the poetic passion, the desire of beauty, the love of art for art's sake" (Pater 312). Besides, beauty is also associated to the mysterious and the religious, as when he calls Burne-Jones "the Archimage of the esoteric unreal" (Wilde 1877, 14), which echoes recurrent contemporary allusions to the mystical or even arcane dimension of Burne-Jones's works. The aura of mystery that surrounds the figures depicted by many artists even led their detractors to mock the directions art was then taking and to parody the rhetoric of enthusiastic critics. Henry Heathcote Statham, in his review of the exhibition of 1877 for Macmillan's Magazine, hopes that the next exhibitions will not display the same "artistic eccentricities, however brilliant" (Statham 118) while the Art Journal's anonymous reviewer of the 1878 follow-up voices his weariness at the "thoughtful and gifted disciples of this quasi-classic, semi-mystic school" (Art Journal, 155). On the contrary, Wilde asserts that "it is at the Grosvenor Gallery that we are enabled to see the highest development of the modern artistic spirit as well as what one might call its specially accentuated tendencies" (Wilde 1879, 24). He was therefore clearly positioning

"Colvin, though he never uses the term "Aestheticism", is considered as one of the main theoreticians of that movement. See Prettejohn 1999, 1-7. 
himself in favour of the new artistic tendencies associated with the "classic" and "Aesthetic" trends in painting.

Indeed Wilde, like other reviewers supportive of such pictorial movements, actually evokes only twenty or so artists out of the sixty-four who were exhibited at the Grosvenor Gallery in 1877. What is more, he chooses to dwell more lengthily on the classic-cumAesthetic painters. He does mention Millais's portraits as well as a number of lesser-known artists, and he does dwell on Tissot—whose subjects he rejects — and Heilbuth, whose jolly genre scenes of Roman clerics, families and choirboys seem to appeal to him. However, if one sifts through Wilde's choices and compares them with those effected by five other criticsRossetti, Stephens, Colvin, Atkinson and Statham-, one notices the pre-eminence of the artists associated to the above-mentioned artistic trends. All six comment on Edward BurneJones and John Roddam Spencer Stanhope; five discuss Walter Crane, Lawrence AlmaTadema and George Frederic Watts; four William Blake Richmond; and three John Melhuish Strudwick and Albert Moore. Most reviewers - even those who were not totally favourable to them, such as Atkinson and Statham - therefore give pride of place to these new trends in their accounts.

What I particularly want to dwell upon here is Wilde's response to an aesthetic that is founded on the blending of various polarities and on a mood of melancholy. This is an eclectic aesthetic that draws on classical and Renaissance sources. Central in this outlook is the idea that Greek forms, filtered through Renaissance painting, are valued for their potential to reach formal perfection and harmony. This is a discourse that recurs in many artists' writings as well as in the art criticism of both theoreticians and journalists. For beauty, in the works Wilde addresses, has to do mostly with figuration and with the body. The modelling of the figures, therefore, is based on a close study of Greek sculpture while the colouring is influenced either by a bright treatment of colour inspired by Florentine painting or by a vaporous treatment of the brush influenced by Venetian painting. This highly eclectic aesthetic leads to bodily types of beauty that are both plastic and sensuous; their contours are derived from Greek statuary and the formalist approach to colour responds to Aesthetic principles, while the puzzling aura that surrounds the figure is quite romantic.

Wilde's texts reflect his attraction for this fundamentally eclectic and ambivalent aesthetics. When commenting on Sapphires, a picture by Albert Moore (1877, oil on canvas, 55.2 x $156 \mathrm{~cm}$, Birmingham Museum and Art Gallery), Wilde insists on the decorative dimension not only of colour but also of the human figure: 
Mr. Albert Moore sends some of his usual pictures of women, which as studies of drapery and colour effects are very charming. One of them, a tall maiden, in a robe of light blue clasped at the neck with a glowing sapphire, and with an orange headdress, is a very good example of the highest decorative art, and a perfect delight in colour. (Wilde 1877, 11)

The female figure becomes a decorative motif among others, an idea that recurs in Colvin's assessments of the painter: he too uses the term "delight" when he praises the "combinations in form and colour" that characterizes Moore's works (Colvin 1877, 832). In fact, Moore was the arch-exponent of "Aestheticism" because of his interest in geometrical, formal and chromatic effects. His decorative treatment of the human figure was grounded on the use of Greek iconographical models-mostly statuary and drapery-, which were considered noble and perfect, notably because of the serenity and emotionlessness of the figures. Frederic Leighton too considers classic subjects as "vehicles of pure abstract form" in a letter of 1873 (see J. Comyns Carr 98), an idea that many artists and critics shared. When he evokes Moore's Sapphires, Colvin depicts a "stately figure of a woman of fair countenance, with the flesh and modellings perfectly rendered" (Colvin 1877, 832). This points to the noble grandeur and the formal perfection of the figure, which is due to the fact that the sculptural model takes the figure away from the individual and the particularized towards the idealized and the universal.

Many of these painters held that the quest for beauty entailed a return to Greek sculptural forms and to a highly aesthetic and decorative treatment of colour. In his first essay, Wilde is highly impressed by the dazzling colours of the canvases he discusses. However, his attitude to colour is quite complex and he does not always adhere to the choices these painters advocated or to the tenets articulated by theoreticians sympathetic to their works. His passion for colour seems to jar with his personal predilection for the link between painting and the literary — at the expense of a purely visual and aesthetic appraisal of the works. For example, Wilde rejects the colour used for the female mourners in William Blake Richmond's Electra at the Tomb of Agamemnon (1874, oil on canvas, 170.2 x $157.5 \mathrm{~cm}$, Art Gallery of Ontario). Although he finds the subject "magnificent"-probably because it is taken from Greek tragedy, a genre he particularly appreciated-he rejects the chromatic treatment of the women's clothes:

[T] here is a want of humanity in the scene: there is no trace of that passionate Asiatic mourning for the dead to which the Greek women were so prone, and which Aeschylus describes with such intensity; nor would Greek women have come to pour libations to the dead in such bright-coloured dresses as Mr. Richmond has given them; clearly this artist has not studied Aeschylus' play of the Choephori, in which there is an elaborate and pathetic account of this scene. (Wilde 1877, 9-10) 
These Greek figures, in fact, conform to the extreme formalist version of Aestheticism-one in which the harmony of colour and line are primordial. Richmond uses a statuesque model that enables him to attain expressionlessness and emotionlessness. The canvas is a pure arrangement of line, form and colour. Yet although Wilde lauds Richmond's treatment of the Greek landscape and the flowers, he resents the colours of the draperies and shows some reticence when faced with the calm of the women, who should have expressed pathos. So he emerges as a literal reader of Aeschylus rather than as a supporter of an art that favours form over meaning and that distances itself from literary sources. ${ }^{7}$ Such commitment to the text diverges from the aesthetic aims which some painters were then espousing and which was one of the reasons for the prominence of such static, melancholy and impassive figures.

Each of the paintings displayed provides the opportunity for Wilde to revel in the colours of the flowers, skies and landscapes. But his vision of colour is also a response to each painter's manner, and so it varies exactly as his or her approach does. Yet colour also acquires a symbolical dimension. In particular, Burne-Jones's canvases are the sites of a special investment. Wilde compares William Holman Hunt's treatment of colour-which, unlike a number of critics, he finds too imitative-with Burne-Jones's imaginative and symbolizing handling. Colour has the potential to evoke moods and emotions:

Burne-Jones, on the contrary, is a dreamer in the land of mythology, a seer of fairy visions, a symbolical painter. He is an imaginative colourist too, knowing that "all colour is no mere delightful quality of natural things, but a spirit upon them by which they become expressive to the spirit," as Mr. Pater says. (Wilde 1877, 6-7)

The quotation is drawn from Walter Pater's description of Botticelli's Birth of Venus. In that case, the colour of the goddess of love is associated with morbidity. Wilde adopts Pater's notion that colour is evocative of mood, and in Burne-Jones's case, it creates a halo of mystery around the figures: what prevails is ambiguity and trouble.

Not only do the colours in Burne-Jones's paintings intrigue Wilde but so do his static, calm and dreamy figures. What indeed emanates from the paintings of many of these "classic" or "Aesthetic" painters is the aesthetics of mystery, oneirism and fantasy. These paintings give Wilde the inspiration for a poetical transcription of his emotions when faced with the self-enclosed and narcissistic figures represented. For example, Wilde's mesmerized evocation of Burne-Jones's Mirror of Venus (1875, oil on canvas, 120 x $200 \mathrm{~cm}$, Museu Calouste Gulbenkian, Lisbon) is a vibrant tribute to the painting's haunting atmosphere:

'In her study of his two Grosvenor essay, M. Symington argues that Wilde questions the relation between criticism and pictorial creation in a way that establishes a hierarchy among the arts: criticism is not only autonomous but superior to the artwork. She thoroughly analyses how Wilde starts from the painting to deploy his own artistic imagination and to transpose the visual experience into words. The artwork therefore functions as a kind of stepping-stone to an imaginative and poetical recreation (Symington $78 \mathrm{sq}$ ). 
[E]ight girls, handmaidens of the Goddess of Love, are collected by the margin of a long pool of clear water, whose surface no wandering wind or flapping bird has ruffled; but the large flat leaves of the water-lily float on it undisturbed, and clustering forget-me-nots rise here and there like heaps of scattered turquoise [...] each girl is reflected as in a mirror of polished steel. Some of them bend over the pool in laughing wonder at their own beauty, others, weary of shadows, are leaning back, and one girl is standing straight up; and nothing of her is reflected in the pool but a glimmer of white feet. (Wilde 1877, 16)

This is a highly literary description, replete with rhythmical and balanced sequences a well as with sonorous and sensuous alliterations and assonances. But it is also quite subjective. For there are in fact ten figures in Burne-Jones's canvas and none of them is laughing. What perhaps matters to Wilde is to emphasize the ambivalence of the image, in which a happy note contrasts with a mood of sadness. The women are indeed "weary of their shadows"-a Tennysonian theme and phrasing, except that the mirror through which the Lady of Shallot is doomed to look at the world is transposed here into the "polished" surface of the water. What is more, the pool does not reflect the loved one, but the desiring and wistful women, who seem shut out from the bliss of passion. In this barren land, and despite the blooming flowers, Venus and her eager female attendants are doomed to contemplate their reflections only. What is reflected of the anxious goddess of carnal passion is only a virginal "glimmer of white feet"-which, for Venus, is quite unusual. Besides, the forget-me-nots evoke a male other who is absent. In his evocation, Wilde responds to the ambivalent aesthetics which typify this canvas as well as many others: the figures are both beautiful and melancholy, troubled and languid; their beautiful bodies are the sites of an erotic investment as well as of symptoms of anguish. Wilde therefore shares Burne-Jones's ambivalent treatment of female desire and anxiety. In this, he was not alone. Colvin too is inspired by Venus's "clear pale face and pale limbs scarcely kindled with human blood, a light of the far-off sea in her grey and wistful eyes" (Colvin 1877, 827). Colouring, here, is evocative of ghostliness and sorrow. As for Rossetti, he too evokes the ambivalent beauty of Burne-Jones's haunting figures: the “predominant quality of Mr. Burne-Jones's art is 'Weltschmerz, world-pang,' and it is "removed out of the humanly personal relation to which the feeling so properly belongs into that semi-abstract region where passion subsides into yearning, and to exist in bodily presence is almost to do something, and to look is to live" (Rossetti 396). Wilde had been engaged in a correspondence with W.M. Rossetti, who sent him a response in August 1877 (Elmann 79). These figures, who seem to reflect some vague psychosexual concerns, give way to lyrical and emotional descriptions.

Wilde reflects the fascination with pallid and inexpressive female figures that characterize many of the paintings shown. In the 1879 article, Wilde describes Burne-Jones's 
version of the "Greek legend of Pygmalion" (Edward Burne-Jones, The Pygmalion and the Image Series, 1875-8, oil on canvas, Birmingham Museum and Art Gallery) —described as both Christian and "pure Greek", which was yet another form of hybridity-he refers to Galatea as a "passionless, pale woman" (Wilde 1879, 25). This was a topos of the "classical" as well as of the "Aesthetic" paintings of the time and of their reception, which revelled in such ambiguous female figures of desire. They are often associated to the colour white as well as to the motif of fragile flowers. Wilde refers to "[t]he white body of the dying girl, drooping like a pale lily" in his description of G.F. Watts's Orpheus and Eurydice (1870-2, oil on canvas, $56 \times 76 \mathrm{~cm}$, private collection) and this is associated with another typical polarity: the colour of the woman's flesh contrasts with "the clinging arms of her lover, whose strong brown limbs seem filled with all the sensuous splendour of passionate life". The two figures, then, "form a melancholy and wonderful note of colour to which the eye continuously returns as indicating the motive of the conception" (Wilde 1879, 26). Considering the subject - the death of his beloved at the moment when Orpheus at last is allowed to embrace her-the "motive" may have to do with unrequited yearning. The desiring male encloses a virginal woman whose life is cut like a flower's, and the possibility of sexual reunion ends in death. The difference in flesh colour that Wilde notes is a fundamental academic pictorial convention - one which posits a gendered contrast of colour female and male flesh. This often goes with another feature of "classical" painting - that is, the respective treatment of the male and the female body with, on the one hand, the muscular body (often modelled on sculptural athletes or on Michelangelo's figures) and, on the other hand, the soft female body and its delicate flesh tints. When assessing Burne-Jones's Days of Creation (The Days of Creation series, 1870-6, watercolour and gouache on panel, Fogg Art Museum, Harvard University), Wilde indeed reproduces such recurrent polarities when he refers to "Adam's strong brown limbs and hero form" and to "the pale, beautiful body of Eve" (Wilde 1877, 15).

A far cry from the frail, flower-like and virginal girl stands the emasculating woman, who in Wilde's essays acquires an emblematic status. He devotes long passages to the witch Vivien, described by Burne-Jones in The Beguiling of Merlin (1872-77, oil on canvas, $186 \mathrm{x}$ $111 \mathrm{~cm}$, Lady Lever Art Gallery, Port Sunlight, Merseyside). The wizard is imprisoned in a vegetal and floral tangle that finds a visual echo in the woman's hair, which is a coil of headless serpents. Thanks to his alliterative prose, Wilde conjures up a mesmerizing description of this arch-castrating woman- "a tall, lithe woman, beautiful and subtle to look on, like a snake" (Wilde 1877, 7). When he assesses G.F. Watts's Love and Death (c. 1874-7, 
oil on canvas, 248.9 x $116.8 \mathrm{~cm}$, Whitworth Art Gallery, Manchester University), Wilde takes up the trope of the Gorgon: he compares the draped figure of Death to a "Medusa-like [...] grey phantom [who] turns all it looks upon to stone" (Wilde 1877, 13), although the figure turns her back to the onlooker and although her head is hidden under her drapery. In Wilde's description, the figure's gaze — which the painter does not represent-becomes a central element of the interaction between Death and Love, whose terrified eyes are seen frontally.

However, what is at also stake in Wilde's comment is another kind of trouble - one that revolves around male desire and the anguish of death. Wilde dwells on the smooth and sensuous contours of the youthful male figure, who is the locus both of an erotic charge and of a tragic investment: "Love, a beautiful boy with lithe brown limbs and rainbow-coloured wings, all shrinking like a crumpled leaf, is trying, with vain hands, to bar the entrance" (Wilde 1877, 7). This is the first articulation of the topos of the attractive but ill-fated youth which recurs in his later works. The internal rhymes and the play on assonances and alliterations convey his emotions as he relishes in the colours and texture of his limbs. Wilde also takes up an element of Watts's paintings that recurs in the contemporary reception of that artist - that is, his combination of Michelangelesque line and Venetian brushwork. What many contemporaries found puzzling was the disruption of a central hierarchy which had been established by the Vasarian tradition: drawing, that is, line (disegno), is privileged because it is associated to reason and to the masculine, while colour (colore) is deemed inferior because it is associated to matter, to the feminine and thus to sensuousness. But Wilde and other critics were particularly receptive to the blurring of these aesthetic and gendered distinctions.

Such mix of genres crystallises in Wilde's comment on Stanhope's Love and the Maiden (1877, tempera, gold paint and gold leaf on canvas, 86.4 x $50.8 \mathrm{~cm}$, Fine Arts Museums of San Francisco), which depicts the intrusion of Love upon a young girl. He first reconstructs the story that precedes the scene: "a girl has fallen asleep in a wood of olive trees". Then, he asks: "who would have dreamed of finding Eros there?" (Wilde 1877, 12). To Wilde, the picture represents the sexual awakening of a young girl who "wakes up, as one wakes from sleep one knows not why, to see the face of the boy Love". He constructs the young woman as virginal and passive: "it would have been a relief had the girl been dressed in pure white," which associates the girl with virginity. However, unlike Wilde, most reviewers elude the sexual dimension of the painting and concentrate instead on the effects created by the composition, the colours, the figures or the floral decoration. Only 
W.M. Rossetti touches upon what is at stake in the painting. He associates the young god with fertility and sexual stamina: "Love, a red-winged and beautiful youth, holding a golden bow, sets his right knee against the trunk of a tree twined with oleander, which flowers profuselybursting into blossom, as one might infer, at the very touch of the all-animating all-subduing god"; the girl appears as a passive sleeping beauty who is "roused now for the first time from the long slumber of the heart of girlhood" (Rossetti 467). All in all, his description reflects the picture, which depicts a youth who violently intrudes upon a recoiling girl. Again, the representation here is highly ambivalent as far as desire is concerned. Yet it is not this theme, however central, which seems to attract Wilde's attention. For he then embarks on a long passage on the boy himself:

A rose-garland presses the boy's brown curls, and he is clad in a tunic of oriental colours, and delicately sensuous are his face and his bared limbs. His boyish beauty is of that peculiar type unknown in Northern Europe, but common in the Greek islands, where boys can still be found as beautiful as the Charmides of Plato. Guido's St. Sebastian in the Palazzo Rosso at Genoa is one of those boys, and Perugino once drew a Greek Ganymede for his native town, but the painter who most shows the influence of this type is Correggio, whose lily-bearer in the Cathedral at Parma, and whose wildeyed, open-mouthed St. John in the 'Incoronata Madonna' of St. Giovanni Evangelista, are the best examples in art of the bloom and vitality and radiance of this adolescent beauty. (Wilde 1877, 12-13)

The boy Love embodies a general aesthetics of hybridity. He corresponds to Greek and Renaissance models, and he evokes Platonic and Christian literary or artistic sources. The allusion to Charmides points to the Dorian contours of sculpture and to notions such as rationality, austerity and simplification, while the "Oriental" connotes the feminine, the coloured and the hybrid. Love is exceedingly "sensuous" and androgynous, as Wilde's description of his hair and body shows. His use of his floral images ("rose" and "lily") further links him to the feminine. So he transcribes Stanhope's sensual representation of the male body into a personal evocation that looks towards long-established homoerotic figures of Western art and literature. Wilde's aesthetic predilection is quite unique, although some reviewers let out some homoerotic notes at times. Colvin, for example, lyrically dwells on the figure's "rich-limbed rose-winged Love" (Colvin 1877, 829). But no other critic goes as far as Wilde in turning such figures into a nexus of homoerotic visual and literary references.

Writing these two reviews of the Grosvenor Gallery exhibitions was for Wilde "a way of mapping out his personal literary territory", to take up Stokes's expression (Stokes 69), as well as the occasion to promote his personal aesthetic - one that was deeply marked by the new pictorial trends of the $1860 \mathrm{~s}-1870 \mathrm{~s}$. Wilde's aesthetics is shaped by the images he gazed on at the Grosvenor Gallery exactly as his imaginative powers are influenced by the poetical 
language of contemporary criticism of that painting. What is obvious in these texts is that seeing these particular paintings was a key moment for Wilde. These two essays, therefore, are the first testimonies to his admiration for an aesthetic vision he kept promoting in his lectures and essays from the early 1880s onwards. Wilde enters a general network of inter-art connections and he joins those artists and writers who among other accomplishments promoted an aesthetic of ambiguity and hybridity.

Anne-Florence Gillard-Estrada Université de Rouen Laboratoire ERIAC

\section{Bibliography}

[Anon.]. "The Grosvenor Gallery.” Art Journal, n.s. 17 (1878): 155.

Aquien, Pascal. Oscar Wilde. Les mots et les songes. Croissy-Beaubourg : Aden, 2006.

Atkinson, Agnes D. “The Grosvenor Gallery.” Portfolio, vol. 8 (1877): 97-9.

Barrow, Rosemary J. The Use of Classical Art and Literature by Victorian Painters, 18601912. Lewiston, Queenston and Lampeter: The Edwin Mellen Press, 2007.

Casteras, Susan P., and Colleen Denney, eds. The Grosvenor Gallery: A Palace of Art in Victorian England. New Haven: Yale Centre for British Art and Yale University Press, 1996.

Colvin, Sidney. "English Painters and Painting in 1867." Fortnightly Review 2 (1 Oct. 1867): 464-76.

—. “The Grosvenor Gallery.” Fortnightly Review vol. 27, 21 (June 1877): 820-33.

Comyns Carr, J. Some Eminent Victorians: Personal Recollections in the World of Art and Letters. London: Duckworth \& Co., 1908.

Denney, Colleen. At the Temple of Art: the Grosvenor Gallery, 1877-1890. London: Fairleigh Dickinson University Press/Associated University Press, 2000.

Ellmann, Richard. Oscar Wilde. London: Hamish Hamilton, 1987.

Newall, Christopher. The Grosvenor Gallery Exhibitions: Change and Continuity in the Victorian Art World. Cambridge: Cambridge University Press, 1995.

[Walter Pater]. "Poems by William Morris." (unsigned review) Wetsminter Review (October 1868): 300-12.

Prettejohn, Elizabeth, ed. After the Pre-Raphaelites: Art and Aestheticism in Victorian England. Manchester: Manchester University Press, 1999. 
-. Art for Art's Sake: Aestheticism in Victorian Painting. New Haven, London: Yale University Press, 2007.

Ross, Iain. Wilde and Ancient Greece. Cambridge: Cambridge University Press, 2013.

Rossetti, W. M. “The Grosvenor Gallery.” Academy vol. 11 (5 May 1877): 396-7.

[F.G. Stephens]. "The Grosvenor Gallery.” The Athenaeum 2584 (May 5 1877): 583-4.

Stokes, John. "Wilde the Journalist." The Cambridge Companion to Oscar Wilde. Ed. Peter Raby. Cambridge: Cambridge University Press, 1997. 69-79.

Staley, Allen. The New Painting of the 1860s: Between the Pre-Raphaelites and the Aesthetic Movement. New Haven: Paul Mellon Centre for Studies in British Art/Yale University Press, 2011.

Statham, H. Heathcote. “The Grosvenor Gallery.” Macmillan's Magazine 36 (June 1877): $112-8$.

Sussman, Herbert. "Criticism as Art: Form in Oscar Wilde's Critical Writings.” Studies in Philology 70.1 (January 1973): 108-122.

Swinburne, A.C. William Blake: A Critical Essay. London: John Camden Hotten, 1868.

Symington, Miceala. Écrire le tableau. L'approche poétique de la critique d'art à l'époque symboliste. Bern: Peter Lang, 2006.

Wilde, Oscar. "The Grosvenor Gallery, 1877." The Collected Works of Oscar Wilde. Vol. XIV: Miscellanies. Ed. Robert Ross. London: Methuen, 1908. 5-23.

-. "The Grosvenor Gallery, 1879." The Collected Works of Oscar Wilde. Vol. XIV: Miscellanies. Ed. Robert Ross. London: Methuen, 1908. 24-29. 